\title{
Financing Preferences and Optimization Recommendations for Listed Companies in China
}

\author{
Xige Dai \\ Wuhan University of Technology, Hubei 430070, China
}

\begin{abstract}
Since its establishment, China's capital market has made great progress and has also promoted the formation of various financing channels. However, in recent years, the current situation of China's capital market, compared with the western developed country, China's listed companies gradually form the phenomenon of equity financing preference, which is not conducive to the basic function of China's securities market play and healthy development. Therefore, this paper makes a detailed study of the financing preference characteristics such as equity financing, which is significantly higher than debt financing, Short-term debt financing is higher than Long-term debt financing, and insufficient endo source financing.
\end{abstract}

Keywords: Listed Companies; Corporate Financing Preferences; Financing Optimization.

\section{Introduction}

This paper mainly discusses the internal influence factors and external influence factors of listed companies in China. Internal factors include the size of the company, the company's capital structure, the company's profitability, and solvency and Non-debt tax shield. External influences include external policies and external systems.

\section{Organization of the Text}

\subsection{Internal Influencers}

\subsubsection{Company Size}

"Generally speaking, the larger the company, the greater its influence, the higher its reputation, and its stability." Larger companies, their business practices are more diversified, the more diversified the ability to spread the risk of the company. Moreover, the information disclosure system of large companies is relatively perfect, which is conducive to the external investors to make a more comprehensive understanding of the company and reduce the moral hazard of reverse selection. As a result, the larger the company, the more likely it is to be bond finance.

\subsubsection{The Capital Structure of the Company}

The capital structure of a company is usually measured by our asset-liability ratio. [1] The ratio of assets to liabilities refers to the total liability divided by the percentage of total assets, i.e., the ratio of total liabilities to total assets. The ratio of assets and liabilities reflects the proportion of total assets raised through borrowing, and can also be measured to the extent to which an enterprise protects the interests of creditors in a liquidation. Individual companies are extremely sensitive to their own asset structure, because the higher the asset-liability ratio, meaning that the lower the company's profitability, the higher the financial risk, cash flow may be a problem, further leading to the breakdown of the capital chain, if the company can't repay the debt in a timely manner, then there will be no external investors willing to invest in the company, thereby affecting the company's debt investment.

\subsubsection{Profitability and Solvency of the Company}

In general, the stronger the company's profitability, the more endo source financing is sufficient when the company is expanding its size. However, if the company's profitability is very poor, only external bond financing can be chosen. Also, if the company's cash flow is no problem, liquidity capacity, then it means that the solvency of debt, generally in this case the company's credibility is 
very strong, the outside world is very optimistic about the future development of the company, then the company will be more easily through the way of bond financing to obtain funds.

\subsubsection{Non-debt Tax Shield}

Non-debt tax shield refers to the reduction of tax revenue caused by the depreciation of fixed assets, according to the relevant accounting standards, the depreciation of fixed assets is included in the current period expenses, deducted in the pre-tax operating profit, so the Non-debt tax shield can be used as a tax substitute to reduce the corporate tax burden. So, the Non-debt tax shield is negatively correlated with the debt level. If the corporate Non-debt tax shield is high, then the preference for equity financing.

\subsection{External Influencers}

\subsubsection{External Policy}

China's enterprise financing has generally gone through three stages: planned economic financing, transition economic financing, and capital market financing. In the planned economy period, the power is highly centralized, the bank funds are issued by the government departments indicators, in the form of financial allocations into enterprises. After 1979, China began to carry out economic restructuring, the state implemented the policy of transfer of loans. The funds needed for enterprise development are beginning to be met through bank loans, and from the single financial allocation in the past to a situation in which multiple financing methods coexist. After 1990, the stock market appeared in China, to a certain extent to meet the growing financing needs of Chinese enterprises, thus developing into a state of internal financing, borrowing, stock financing coexisting.

\subsubsection{External Regime}

Because China's approval system for stock issuance has a certain hidden credit impact on the issuance of shares of the company, and Chinese companies generally use rights issues and rights issues as an assessment of performance management, which strengthens the company's preference for equity financing.

Not only that, because the ownership and control of the joint-stock ownership enterprise is now separated, so that management in the financing process will not maximize the interests of shareholders as a financing target, but value the enterprise's after-tax profits, but after-tax profits are calculated through the enterprise-related debt financing costs, did not assess the cost of equity financing, so the company's management is more inclined to equity financing.

\section{China's Financing Preference Characteristics}

\subsection{The Proportion of Equity Financing is Significantly Higher than That of Creditor's Rights Financing}

In the theory of eating and the actual situation of listed companies in western developed countries, endogenous financing takes precedence over the choice of external financing. [2] In foreign financing, bond financing takes precedence over equity financing, and the proportion exceeds equity financing. But for Listed companies in China, the data show that equity financing accounts for an average of $50 \%$ in the financing structure and $30 \%$ of bond financing, significantly lower than equity financing.

China's stock market is not sound, the bond market is lagging, the cost of equity financing is much lower than bond financing. Unlike the pressure of dividends and dividends in western developed countries, many listed companies in China are symbolic, and even some companies do not pay dividends all year round, and the relevant regulatory authorities for this aspect of supervision is only soft constraints, so for China, the cost of equity financing is relatively low. Bond financing maturity to repay the principal, regular interest payments, not only high cost but also repayment pressure and risk. Therefore, China's listed companies prefer equity financing. 
Listed companies because of the low cost of equity financing, as the preferred and accounting of the largest financing method. Thus, the risk and uncertainty of financing in the stock market are ignored. Especially in China's stock market is not sound, if the company will be the main channel of equity financing, then once the stock market prices fall sharply, the assets of listed companies will be greatly reduced, seriously affecting the survival and development of enterprises.

\subsection{Short-term Debt Financing is Higher than Long-term Debt Financing}

In the debt financing structure of Listed Companies in China, not only is the debt financing ratio low, but the Short-term debt ratio is higher than the Long-term debt ratio. Generally speaking, enterprises borrow Short-term debt mainly for capital turnover, to solve the problem of capital chain tension, or because accounts receivable recovery is too slow to cause capital constraints, therefore, the characteristics of high current debt ratio reflect the unreasonable debt structure of China's listed companies, indicating that the company's net cash flow is insufficient, need to rely on a large number of Short-term funds to ease the shortage of funds, open the company's continuous business activities.

\subsection{The Proportion of Endo Source Financing is Insufficient}

Table 1. The financing structure of listed companies in China 2012-2016 (units\%)

\begin{tabular}{|c|c|c|c|c|}
\hline Year & $\begin{array}{c}\text { The proportion of } \\
\text { endogenous financing. }\end{array}$ & $\begin{array}{c}\text { The proportion of } \\
\text { external financing. }\end{array}$ & $\begin{array}{c}\text { Equity financing } \\
\text { ratio. }\end{array}$ & $\begin{array}{c}\text { The proportion of bond } \\
\text { financing. }\end{array}$ \\
\hline 2012 & 15.21 & 84.79 & 50.11 & 34.67 \\
\hline 2013 & 17.65 & 82.35 & 49.65 & 32.69 \\
\hline 2014 & 18.71 & 81.29 & 46.49 & 34.79 \\
\hline 2015 & 19.58 & 80.42 & 48.89 & 31.52 \\
\hline 2016 & 19.42 & 80.58 & 51.65 & 28.97 \\
\hline
\end{tabular}

Source: Liu Lei. Discussion on the Optimization of Financing Structure of Listed Companies in China, Time Finance.

According to the data of this year's financing structure of Listed Companies in China from 2012 to 2016 , the proportion of external financing is more than $80 \%$, while the proportion of endo source financing is only $20 \%$, and the huge difference between domestic and foreign source financing shows that China's listed companies have strong foreign financing preferences. According to the factors affecting the financing methods of Listed Companies in China discussed above, the reasons for this strong preference may be internal and external. Internal factors include the lack of understanding of endogenous financing by listed companies in China and the lack of endogenous financing mechanism within the company, which makes undistributed profits eventually distributed to shareholders and management in dividends or other forms, thus making it very small to re-invest in the production and operation of enterprises. External factors include China's economy is currently in a period of rapid development, with the rapid expansion of capital, internal funds can not meet the needs of internal and external expansion, so the company can only through external financing, rapid financing, so as to meet the company's expansion of the size of the requirements. If the listed company's endogenous deficiency, it means that the company's financial strength is weak, the ability to deal with risk is poor, is not conducive to the company's sustainable development. Therefore, china's listed companies this strong preference for foreign financing needs to be improved.

\section{Optimization Recommendations}

\subsection{Improve the Equity Financing System and Weaken the Equity Financing Preference}

The fundamental reason for listed companies' preference for equity financing is the problem of corporate governance structure, therefore, the over-preference of listed companies for equity financing should start with the continuous improvement of the corporate governance structure.[3] First, perfecting the corporate governance structure can not only stay in the form, but we should also 
eliminate the misunderstanding from the ideological concept, and improve the corporate governance structure from the ideological, organizational implementation, in strict accordance with the law of the market economy. Second, we should further improve the Company Law and other relevant laws and regulations, and better regulate the rights, responsibilities, and interests of the shareholders, the board of directors, the managers and the supervisory board of the company, so as to form a legal environment in which different rights subjects check and balance each other. The government and relevant departments should pay attention to the introduction of laws to guide enterprises to establish and improve the corporate governance structure, from the legal and policy of enterprises that really operate in accordance with the modern enterprise system to encourage and support; At the same time, the supervisory board and independent directors should strengthen the supervision role of the company. Third, gradually solve the problem of "one big unit" of state-owned shares. At present, many major shareholders of listed companies by virtue of "one large share", the actual manipulation and control of listed companies, to seek the interests of major shareholders, harm the interests of small shareholders. Therefore, in order to optimize the equity structure and play the role of equity checks and balances, the relevant government departments should adopt various ways to reduce the proportion of state-owned shares, and gradually solve the problem of "one large share" of state-owned shares. Such as the transfer of state-owned shares to private enterprises or foreign-funded enterprises, state-owned share repurchase, share-to-debt, state-owned enterprises strategic restructuring, stateowned enterprises to introduce strategic investors, and other ways to reduce the number of stateowned shares. Fourth, in order to encourage the enthusiasm of operators and maintain the consistency of the interests of operators and owners, we should improve the incentive mechanism of operators, including the annual salary system and the stock option system. In terms of restraint mechanism, we should establish the risk system of the operator, carry out the appraisal system of the operator's operating index, perfect the risk mechanism of the operator, and cultivate the manager's market.[4]

\subsection{Promote the Development of Corporate Bonds and Strengthen the Preference for Debt Financing}

The government should reduce the policy intervention of enterprises looking for bonds in a reasonable range, so that listed companies can promote the marketization of interest rates based on the number of funds required, corporate reputation, repayment capacity, and other demand stakes, and thus promote the rapid development of corporate bonds, to achieve the purpose of strengthening debt financing.

\subsection{Increase the Proportion of Endogenous Financing of Listed Companies}

China should improve its existing tax policy and fiscal policy, effectively expand the scale of internal funds available within the company by regulating the profit distribution and retention of listed companies, and support the proportion of internal financing within the company in its policies.

In accounting, fixed asset depreciation is an important part of endogenous financing, with different methods of depreciation, the income of enterprises is also different, and thus affect the flow of funds. Because the relevant regulations of Chinese accounting make a hard requirement for depreciation method, hindering the company's endogenous financing channels, China should optimize the depreciation of fixed assets, so that companies can flexibly choose depreciation methods, thereby speeding up depreciation, reducing tax expenditure, promoting the accumulation of internal funds, and thus achieve the goal of improving the company's endogenous financing.

In short, equity financing and creditor's rights financing have their advantages and disadvantages, the two to the company's yield will affect each other, enterprises should be a rational combination of their own characteristics of these two financing methods, improve the use of the company's funds so that the company can get better development. For large-scale companies, under the premise of internal financing, appropriate increase in debt financing to achieve greater profitability, and for some smallscale companies, endogenous financing is indeed some difficult, then according to the characteristics 
of the company, it is necessary to the appropriately select bank loans, in order to reduce the pressure on the company, in order to maximize value.

\section{Summary}

Enterprise financing generally refers to the Long-term source of funds of non-financial enterprises, under the market economy, the way of enterprise financing is generally divided into two kinds: First, endogenous financing, that is, their own accumulation of available funds into the investment process. The other is external financing, which refers to the process of capital injection by outside investors or investment institutions to convert funds into shares. The development of enterprises mainly depends on the ability to obtain a stable source of funds, enterprise financing mainly refers to the financing behavior of enterprises in the financial market. Therefore, based on the analysis of the influence factors of China's listed companies financing methods, this paper puts forward three financing optimization proposals from different angles in view of the different preferences of financing methods, in order to promote the healthy growth of Listed Companies in China and the steady development of China's capital market.

\section{References}

[1] Pengwei Zhan: Empirical Research on the Financing Preferences of Listed Companies in China and its Influencing Factors (Graduate Degree, Northeastern University of Finance and Economics, China 2014). p. 27.

[2] Huang Shao'an, Zhang Gang, Equity Financing Preference Analysis of Listed Companies in China. Economic Research, 2001, 11:12-20.

[3] Bo Feng, The current financing status of listed companies in China and the choice of financing methods. Business, 2015 (10).

[4] Fan Lin, the theory and empirical study of the financing preferences of listed companies in China. Peking University Press, 2007.p.26-30. 